\title{
Modelling canopy and litter interception in commercial forest plantations in South Africa using the Variable Storage Gash model and idealised drying curves
}

\author{
H. H. Bulcock and G. P. W. Jewitt \\ Centre for Water Resources Research, University of KwaZulu-Natal, Private Bag X01, Scottsville, 3209, South Africa \\ Correspondence to: H. H. Bulcock (bulcockh@ukzn.ac.za)
}

Received: 25 May 2012 - Published in Hydrol. Earth Syst. Sci. Discuss.: 5 July 2012

Revised: 19 November 2012 - Accepted: 20 November 2012 - Published: 18 December 2012

\begin{abstract}
There remains a gap in the knowledge of both canopy and litter interception processes in forest hydrology and limitations in the models used to represent them. In South Africa, interception is typically considered to constitute only a small portion of the total evaporation and in some models is disregarded. Interception is a threshold process, as a certain amount of water is required before successive processes can take place. Therefore an error or false assumption introduced in modelling interception will automatically introduce errors in the calibration of subsequent models/processes. Field experiments to assess these processes, viz. canopy and litter interception were established for the three main commercial forestry genera in South Africa, namely Pinus, Acacia and Eucalyptus, which are described in a companion paper. Drawing on both field and laboratory data, the "Variable Storage Gash" model for canopy interception and an idealised drying curve litter interception model were developed to represent these processes for South African conditions. The Variable Storage Gash model was compared with the original Gash model and it was found that it performed better than the original model in forests with high storage capacities yet was similar to the original model in stands with a low storage capacity. Thus, the models developed here were shown to adequately represent the interception processes and provide a way forward for more representative water resources planning modelling. It was found that canopy and litter interception can account for as much as $26.6 \%$ and $13.4 \%$ of gross precipitation, respectively, and are therefore important hydrological processes to consider in forested catchments in South Africa. Despite the limitation of both the Variable Storage Gash model and the idealised dry-
\end{abstract}

ing curve litter interception model being reliant on empirical relationships, their application highlights the importance of considering canopy and litter interception in water resources management and planning.

\section{Introduction}

There is a gap in the knowledge of both canopy and litter interception in South African forest hydrology, as well as internationally. Interception is typically considered to constitute only a small portion of total evaporation, and in some models interception is disregarded completely (Gerrits et al., 2010) or merely lumped with total evaporation and not considered as a separate process (Savenije, 2004). If interception is considered, it is usually only canopy interception, whereas litter interception may be as high or even higher (Gerrits, 2007). Interception is a threshold process, so a certain amount of water is required to saturate the canopy and litter storage deficit, and is one of the first to consider in modelling before successive processes such as infiltration and runoff can take place (Bulcock and Jewitt, 2012). Therefore, an error introduced in modelling interception, especially disregarding it, will automatically introduce errors in the calibration of subsequent models/processes (Savenije, 2004).

Interception may be defined as a stock, a flux or more appropriately, as a process. If interception is considered as interception storage $\left(S_{\mathrm{c}}\right)$, then it is defined as the rainfall that is temporarily stored on a surface. As a flux, interception is defined as water that is evaporated over a certain period both during and after an event. However, if interception is 
considered as a process, then it is defined as being part of the rainfall flux that is intercepted by a surface and is subsequently evaporated back to the atmosphere. The interception may be expressed as the sum of the change in interception storage $\left(S_{\mathrm{c}}\right)$ and the evaporation from this stock $\left(E_{i}\right)$ (Gerrits et al., 2010) as shown in Eq. (1).

$I_{1}=E_{i}+\frac{\mathrm{d} S_{\mathrm{c}}}{\mathrm{d} t}$

Currently, only the Rutter and Gash models or their derivatives have been widely adopted to simulate canopy interception (Roberts et al., 2004). In a comprehensive review of 15 rainfall interception models by Muzylo et al. (2009), they showed that the original and revised Gash models were the most extensively applied models, and to a slightly lesser extent, the original and revised Rutter models. As an alternative to the Rutter and Gash type models, Calder (1986, 1996) developed a stochastic model that accounted for varying canopy storage capacity with drop size and, therefore, with rainfall intensity. This highlighted a controversy over whether the canopy storage capacity should be treated as a variable or a fixed parameter (Roberts et al., 2004), which has not been resolved. Bulcock and Jewitt (2012) in a companion paper showed that canopy storage capacity varies with rainfall intensity. Based on these studies, as well as the consideration of Eq. (1), which shows that storage changes with time, the well-recognised Gash model was adapted to account for a variable storage capacity with a varying rainfall intensity by incorporating the methods developed by Calder (1996). In this study, the development of the Variable Storage (VS) Gash model is described and tested against observed data and then compared with the original Gash model (Gash, 1979) to determine if including a change in storage capacity with varying rainfall intensity improves the model output.

The throughfall derived from the VS Gash model was used as an input variable to model litter interception, as it is the throughfall that determines the amount of water that will reach the litter. Unlike canopy interception, which is dependent on many factors including the storage capacity, potential evaporation, rainfall intensity and rainfall duration, litter interception is largely dependent on the storage capacity. This is due to evaporative drivers under the canopy such as radiation, temperature and wind speed being moderated by the above canopy. Therefore, as long as the input of simulated throughfall from the VS Gash model and litter storage capacity is estimated accurately, then the idealised drying curve model should perform well. While the VS Gash model may be considered relatively complex and the idealised drying curves fairly simple, it is important to develop models that are useful at the scale of implementation and can use readily available data. While there are more complex, physicallybased litter interception models, these require input variables and parameters that are not readily available. Thus, it is argued that combining the VS Gash model with the idealised drying curves to simulate total interception achieves a "req- uisite simplicity" (Stirzaker et al., 2010) where irrelevant detail has been discarded but conceptual clarity and scientific rigour retained. In this paper we show how information from field experiments and laboratory analysis to assess canopy and litter interception established for the three main commercial forestry genera in South Africa, as described in the companion paper (Bulcock and Jewitt, 2012) can be used to improve the representation of interception in hydrological models.

\section{Methodology}

\subsection{Study site}

The study took place in the well documented Council for Scientific and Industrial Research (CSIR) Two Streams research catchment, located in the Seven Oaks area, about $70 \mathrm{~km}$ north-east of Pietermaritzburg in the KwaZulu-Natal Midlands. The climate is humid, with an annual rainfall ranging from $800 \mathrm{~mm}$ to $1280 \mathrm{~mm}$ that includes many days of mist. During the study period from April 2008-March 2011, $51 \%$ of the recorded events were less than $1 \mathrm{~mm}$, and $74 \%$ of the events were less than $4 \mathrm{~mm}$ (Bulcock and Jewitt, 2012). The mean annual temperature is $17^{\circ} \mathrm{C}$ and is typical of the inland commercial plantation forestry areas of South Africa. Commercial afforestation has long been practiced in the area and is the most widespread land use, with exotic to South Africa gum (Eucalyptus), pine (Pinus) and wattle (Acacia) being the genera of choice. Sugarcane (Saccharum sp.) is also grown at sites where drainage of cold air is good, ensuring that no frost or only light frost may occur (Everson et al., 2006). In this study, 5 yr old Eucalyptus grandis and Acacia mearnsii, as well as $16 \mathrm{yr}$ old Pinus patula stands, with LAI values of 2.7, 2.3, and 1.9, respectively, were considered.

\subsection{Field data collection}

Gross precipitation and evaporation data were supplied by the CSIR from two automatic weather stations forming part of an ongoing Water Research Commission (WRC) project (Everson et al., 2006). One was for the A. mearnsii and E. grandis sites, which is situated on a tower above the canopy, and the other for the P. patula site situated in the open but not above the canopy and is closer to the study site. The models were developed and validated with canopy and litter interception data collected from April 2008 to March 2011. Data from September 1998 to March 2011 were then used to simulate canopy and litter interception for almost a thirteen-year period. 


\subsubsection{Throughfall and canopy interception measurements}

Throughfall measurements were undertaken using a nest of three V-shaped troughs based on the design of Cuartus et al. (2007) constructed from galvanised sheeting. The dimensions of each trough are $10 \mathrm{~cm}$ wide $\times 200 \mathrm{~cm}$ long. Conventional U- or V-shaped troughs are susceptible to blockage by fallen debris and water loss from splash out; however, this system minimizes splash out by using steep Vshaped sides. The troughs were covered with mosquito netting to minimize the entry of debris, which reduces the demand of cleaning and maintaining the system. A correction factor for each trough was derived from laboratory measurements to account for the initial abstraction from the netting (Bulcock and Jewitt, 2012).The troughs were then connected to a tipping bucket gauge and an event data logger. Because the trough represents a linear and continuous sampling surface, the length scale variation of leaves, branches, and tree crown are assumed to be a representative integral of the throughfall caught (Cuartus et al., 2007). During the study period, canopy interception accounted for between $14.9 \%$ and $27.7 \%$ of gross precipitation. A detailed description of the field measurements and results can be found in the companion paper (Bulcock and Jewitt, 2012).

\subsubsection{Litter interception and water drained into soil measurements}

The litter interception and water that drains into the soil was measured using two round galvanized iron basins that fit into each other. The upper basin, which had a diameter of $0.5 \mathrm{~m}$, was filled with litter and had a geotextile lining on top of a wire mesh base so water could percolate into the lower basin. The water that was collected in the lower basin drained into a tipping bucket and recorded the water that would have drained into the soil. The litter interception was then calculated as the difference between throughfall and the water that otherwise would have drained into the soil. The amount of litter interception measured was about $12.1 \%$ for $P$. patula, $8.5 \%$ for E. grandis, and $6.6 \%$ for A. mearnsii and is described in detail in the companion paper (Bulcock and Jewitt, 2012).

\section{Evolution of the Variable Storage Gash interception model}

The original Gash (1979) and later the revised Gash et al. (1995) model are probably the best known canopy interception models. Both the Gash (1979) and revised Gash et al. (1995) models classify storms according to the amount of gross rainfall $\left(P_{\mathrm{g}}\right)$ generated and then compute interception $(I)$, throughfall $(T)$, and stemflow $\left(S_{\mathrm{f}}\right)$. The Gash (1979), Gash et al. (1995) models, and subsequent Variable Storage (VS) Gash model developed for this study require canopy structure and interception parameters and climate forcing variables as input. In this study, the VS Gash model will be compared to the Original Gash model (Gash, 1979). The storage capacity $\left(S_{\mathrm{c}}\right)$ determined using the Klaasens et al. (1998) "mean method" for the study area will be used in the original Gash model. As reported by Bulcock and Jewitt (2012) these are $0.41 \mathrm{~mm}, 1.07 \mathrm{~mm}$ and $0.92 \mathrm{~mm}$ for E. grandis, A. mearnsii and P. patula, respectively.

The VS Gash model is based on three assumptions, the first two being from the original Gash model:

- the rainfall distribution pattern may be represented as a succession of discrete storms, separated by sufficiently long periods to allow the canopy and trunks to dry (Gash, 1979; Gash et al., 1995), and

- the rainfall and evaporation rates are constant during each storm and may be considered as constant between several storms during the same period (Gash, 1979; Gash et al., 1995).

However, an additional assumption is added:

- the maximum canopy storage capacity $\left(S_{\mathrm{c}}^{\max }\right)$ is linearly related to LAI (van Dijk and Bruinzeel, 2001a, b), but the storage capacity $\left(S_{\mathrm{c}}\right)$ varies with rainfall intensity $(R)$.

The process of interception is a function of several properties of the tree, including branch, stem and crown characteristics, and the structure of the stand (Rutter et al., 1975). Widely spaced trees have larger spaces between them, therefore the ventilation within the stand increases and may result in more rainfall being intercepted and evaporated from the tree. However, tree spacing also affects the leaf area per unit ground area and the spatial distribution of leaf area density and will modify both the available energy and boundary layer conductance of the stand and thus influence the rate of evaporation of intercepted water (McNaughton and Jarvis, 1983 in Teklehaimanot et al., 1991). In the VS Gash model this has been accounted for by using LAI as the primary parameter to describe the canopy structure.

The integrity of the original Gash model has not been jeopardised by the modifications made for the VS Gash model. The model requires the following input variables and parameters to describe canopy interception: gross precipitation, evaporation, rainfall rate, LAI and maximum storage capacity. For stemflow, the additional parameters are trunk storage capacity $\left(S_{\mathrm{t}}\right)$ and the stemflow partitioning coefficient $\left(p_{\mathrm{t}}\right)$. Table 1 summarizes the names of the various versions of the Gash models and authors referred to in this document as well as the variables and parameters used in the models. 
Table 1. Evolution of the various versions of the Gash model referred to in this document and model parameter and variables used ${ }^{1}$.

\begin{tabular}{|c|c|c|c|c|c|}
\hline Parameters & Model(s) & Dimension & Forcing Variables & Model(s) & Dimension \\
\hline$p-$ throughfall coefficient & 1,4 & {$[-]$} & $P_{\mathrm{g}}-$ gross precipitation & $1,2,3,4$ & {$\left[\mathrm{~L} \mathrm{~T}^{-1}\right]$} \\
\hline$p_{\mathrm{t}}-$ trunk fraction coefficient & $1,3,4$ & {$[-]$} & $E$ - evaporation & $1,2,3,4$ & {$\left[\mathrm{~L} \mathrm{~T}^{-1}\right]$} \\
\hline$S_{\mathrm{t}}-$ trunk storage & $1,2,3,4$ & [L] & $R$ - rainfall rate & $1,2,3,4$ & {$\left[\mathrm{~L} \mathrm{~T}^{-1}\right]$} \\
\hline$P_{\mathrm{g}}^{\prime}$ - rain to fill canopy & $1,2,3,4$ & {$\left[\mathrm{~L} \mathrm{~T}^{-1}\right]$} & & & \\
\hline$S_{\mathrm{c}}-$ canopy storage capacity & $1,2,3,4$ & [L] & Output Variables & Model(s) & Dimension \\
\hline$S_{\mathrm{c}}^{\max }-$ maximum canopy storage capacity & $2,3,4$ & [L] & $I$ - interception & $1,2,3,4$ & {$\left[\mathrm{~L} \mathrm{~T}^{-1}\right]$} \\
\hline$S_{\mathrm{e}}$ - elemental storage & 4 & [L] & $S_{\mathrm{f}}-$ stemflow & $1,2,3,4$ & {$\left[\mathrm{~L} \mathrm{~T}^{-1}\right]$} \\
\hline$S_{\mathrm{e}}^{\max }-$ maximum elemental storage & 4 & [L] & $T$ - throughfall & $1,2,3,4$ & {$\left[\mathrm{~L} \mathrm{~T}^{-1}\right]$} \\
\hline$c$ - canopy cover & $2,3,4$ & {$[-]$} & & & \\
\hline$q$-drop retention & 4 & {$[-]$} & & & \\
\hline$v$-drop volume & 4 & [L] & & & \\
\hline$v_{\mathrm{O}}-$ drop volume with zero kinetic energy & 4 & [L] & & & \\
\hline$a$ - scaling parmeter & 4 & {$[-]$} & & & \\
\hline$b$ - scaling parameter & 4 & {$[-]$} & & & \\
\hline LAI - leaf area index & 3,4 & {$[-]$} & & & \\
\hline Model & & & \multirow{5}{*}{\multicolumn{3}{|c|}{$\begin{array}{l}\text { Author } \\
\text { Gash (1979) } \\
\text { Gash et al. (1995) } \\
\text { van Dijk and Bruijnzeel (2001) } \\
\text { This study }\end{array}$}} \\
\hline 1 - Original Gash model & & & & & \\
\hline 2 - Revised Gash model & & & & & \\
\hline 3 - Modified Gash model & & & & & \\
\hline 4 - Variable Storage Gash model & & & & & \\
\hline
\end{tabular}

${ }^{1}$ Parameters are considered to be time-invariant and physical descriptions of surface and subsurface characteristics, and variables fluxes (time-variant) of water and energy (Moradkhani et al., 2005).

\subsection{Interception parameters and variables}

One of the most important parameters in all versions of the Gash model, including the VS Gash model, is the rain to fill canopy storage $\left(P_{\mathrm{g}}^{\prime}\right)$ which is described by Eq. (5) from the original Gash model (Gash, 1979):

$P_{\mathrm{g}}^{\prime}=-\ln \left(1-\frac{E}{R\left(1-p-p_{t}\right)}\right) S_{\mathrm{c}}\left(\frac{R}{E}\right)$.

In this equation, the main term is $S_{\mathrm{c}}(R / E)$, which is the amount of rain needed to fill the storage given that most of the rain passes through the tree canopy. It must be noted that it is impossible for $E / R>\left(1-p-p_{\mathrm{t}}\right)$, because $\left(1-p-p_{\mathrm{t}}\right)$ equals interception and canopy drip throughfall, whereas $E / R$ is only interception.

The rain to fill the trunk storage $\left(P_{\mathrm{t}}^{\prime}\right)(\mathrm{Gash}, 1979)$ is described by Eq. (6):

$P_{\mathrm{t}}^{\prime}=S_{\mathrm{t}} / p_{\mathrm{t}}$

The stemflow partitioning coefficient $\left(p_{\mathrm{t}}\right)$ is the fraction of rain that runs down the stem of a tree during a storm, and the trunk storage capacity $\left(S_{\mathrm{t}}\right)$ is the total amount of water the trunk can hold. The intercepted coefficient is therefore the fraction of rain held in the canopy during a storm and is described as $\left(1-p-p_{\mathrm{t}}\right)$.

\subsection{Analytical model equations}

The equations common to the original Gash (1979) and VS Gash models and used to distribute rainfall from individual storms between the different storage terms are described below. Some are constant for all storms while others depend on the actual rainfall amount.

For $(m)$ small storms, where the rainfall amount is insufficient to saturate the canopy (i.e. $P_{\mathrm{g}}<P_{\mathrm{g}}^{\prime}$ ), the evaporation from the canopy $\left(I_{\mathrm{c}}\right)$ is described as Eq. (7):

$I_{\mathrm{c}}=\left(1-p-p_{\mathrm{t}}\right) \sum_{j-1}^{m}\left(P_{\mathrm{g}}, j\right)$.

For $(n)$ large storms (i.e. $P_{\mathrm{g}}>P_{\mathrm{g}}^{\prime}$ ), evaporation is considered in four phases (Eqs. 8 to 11):

evaporation during wetting phase

$I_{\mathrm{w}}=n\left(1-p-p_{\mathrm{t}}\right) P_{\mathrm{g}}^{\prime}-n S_{\mathrm{c}}$,

evaporation of saturated canopy

$I_{\mathrm{s}}=\left(\frac{E}{R}\right) \sum_{j-1}^{n}\left(P_{\mathrm{g}}, j-P_{\mathrm{g}}^{\prime}\right)$,

evaporation after rain ceases

$I_{\mathrm{a}}=n S_{\mathrm{c}}$ 


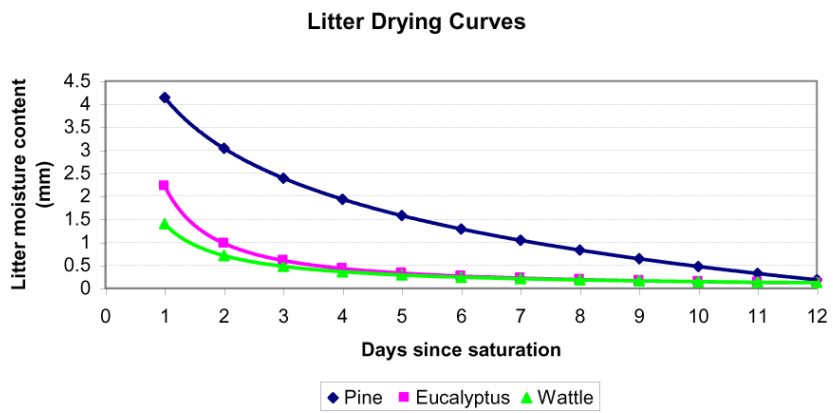

Fig. 1. Idealised drying curves derived from field and laboratory experiments for three litter types in the KZN midlands.

evaporation from trunks, for $q$ storms $\left(P_{\mathrm{g}} \geq P_{\mathrm{t}}^{\prime}\right)$

$I_{\mathrm{t}}=q S_{\mathrm{t}}$,

or for $m+n-q$ storms $\left(P_{\mathrm{g}}<P_{\mathrm{t}}^{\prime}\right)$,

$I_{\mathrm{t}}=p_{\mathrm{t}} \sum_{j-1}^{m+n-q}\left(P_{\mathrm{g}}, j\right)$

For all storms, irrespective of size, the stemflow $\left(S_{\mathrm{f}}\right)$ (Eq. 12) and throughfall (T) (Eq. 13) are considered as

$S_{\mathrm{f}}=p_{\mathrm{t}}\left(P_{\mathrm{g}}-P_{\mathrm{t}}^{\prime}\right)$

$T=P_{\mathrm{g}}-I-S_{\mathrm{f}}$

The stemflow is the product of the stemflow partitioning coefficient $\left(p_{\mathrm{t}}\right)$ and the difference between gross precipitation and rain to fill the trunk storage. Throughfall is simply the difference of gross precipitation, interception loss and stemflow.

\subsection{Canopy structure parameters}

Gash et al. (1995) introduced the canopy cover fraction $(c)$ to account for inadequacies in the simulation of sparse canopies in the original model. Van Dijk and Bruijnzeel (2001a, b) then modified the revised Gash et al. (1995) model, allowing it to be applied to rapidly growing vegetation where the LAI is changing over time. The VS Gash model now introduces a vegetation/species-specific parameter, termed the maximum elemental storage $\left(S_{\mathrm{e}}^{\max }\right)$, which accounts for the water holding characteristics of the canopy and is described more fully in Sect. 4.4 below. LAI is defined as the cumulative onesided area of leaves per unit area. In this model, LAI and $c$ are related to one another via the Beer-Lambert equation (Eq. 14) that describes the attenuation of radiation (i.e. photosynthetically active radiation, PAR) as a function of LAI. PAR, however, does not penetrate far through leaves, therefore the Beer-Lambert equation may be expressed in terms of canopy cover fraction using similar parameters. The relationship between $c$ and LAI is thus given by Eq. (14), where
Table 2. Drying curve equations and litter storage capacity derived from field and laboratory experiments for three litter types in the KZN Midlands.

\begin{tabular}{lrrr}
\hline & Drying curve equations & $\begin{array}{r}\text { Litter } \\
\text { storage } \\
\text { capacity } \\
(\mathrm{mm})\end{array}$ & $\begin{array}{r}\text { Litter } \\
\text { thickness } \\
(\mathrm{mm})\end{array}$ \\
\hline Species & $\mathrm{y}=2.2202(\mathrm{x})^{-1.1879}$ & 2.6 & 38 \\
E. meandis & $\mathrm{y}=1.40(\mathrm{x})^{-0.983}$ & 1.8 & 20 \\
P. patula & $\mathrm{y}=-1.5935 \ln (\mathrm{x})+4.1419$ & 4.5 & 97 \\
\hline
\end{tabular}

the extinction coefficient $k=0.5$ (Landsberg and Waring, 1997; Battaglia et al., 2004) was used in the simulation of the Two Streams catchment. Gazarini et al. (1990) found that a value of $k=0.50$ was appropriate in their study of $E$. globulus, while Pierce and Running (1988) and Sampson and Lee Allen (1998) used values of 0.52 and 0.60 for pine, respectively. No values for Acacia could be found.

$c=1-e^{-k \mathrm{LAI}}$

The throughfall coefficient $(p)$ is the fraction of rain that passes through a canopy during a storm without touching the canopy and can be described as $p=1-c$ (van Dijk and Bruijnzeel, 2001a).

\subsection{Storage capacity and drop size}

An often ignored factor when simulating or measuring canopy interception is the raindrop size. The importance of drop size when determining canopy interception losses was first established through experimental work in the tropical climates of Indonesia and India by Calder (1986). Calder (1986) developed a stochastic interception model that predicts that for storms with the same total rainfall, interception losses would be larger for those with smaller drop sizes. The model also considers the drop retention by the canopy, and is partially dependent on the kinetic energy and hence drop size. The ability of a canopy to retain raindrops is parameterised in the model by a drop retention factor $(q)$ $\left(\mathrm{mm}^{-2}\right)$. The drop retention is dependent upon the size and kinetic energy of the impacting drop, as well as canopy properties such as wettability and leaf angle (Hall, 2003).

To incorporate the dependence of $q\left(\mathrm{~mm}^{-2}\right)$ on both drop volume and therefore kinetic energy to form the VS Gash model, a vegetation/species specific parameter is introduced, termed the maximum elemental storage $\left(S_{\mathrm{e}}^{\max }\right)(\mathrm{mm})$ and is expressed in Eq. (15). This is calculated by considering drops impacting the surface with a kinetic energy as close to zero as possible to determine the maximum storage capacity $\left(S_{\mathrm{c}}^{\max }\right)$, which according to Calder (1996) are events with an intensity of less than $0.36 \mathrm{~mm} \mathrm{~h}^{-1}$. The $S_{\mathrm{e}}^{\max }$ values used in this study are as follows: 

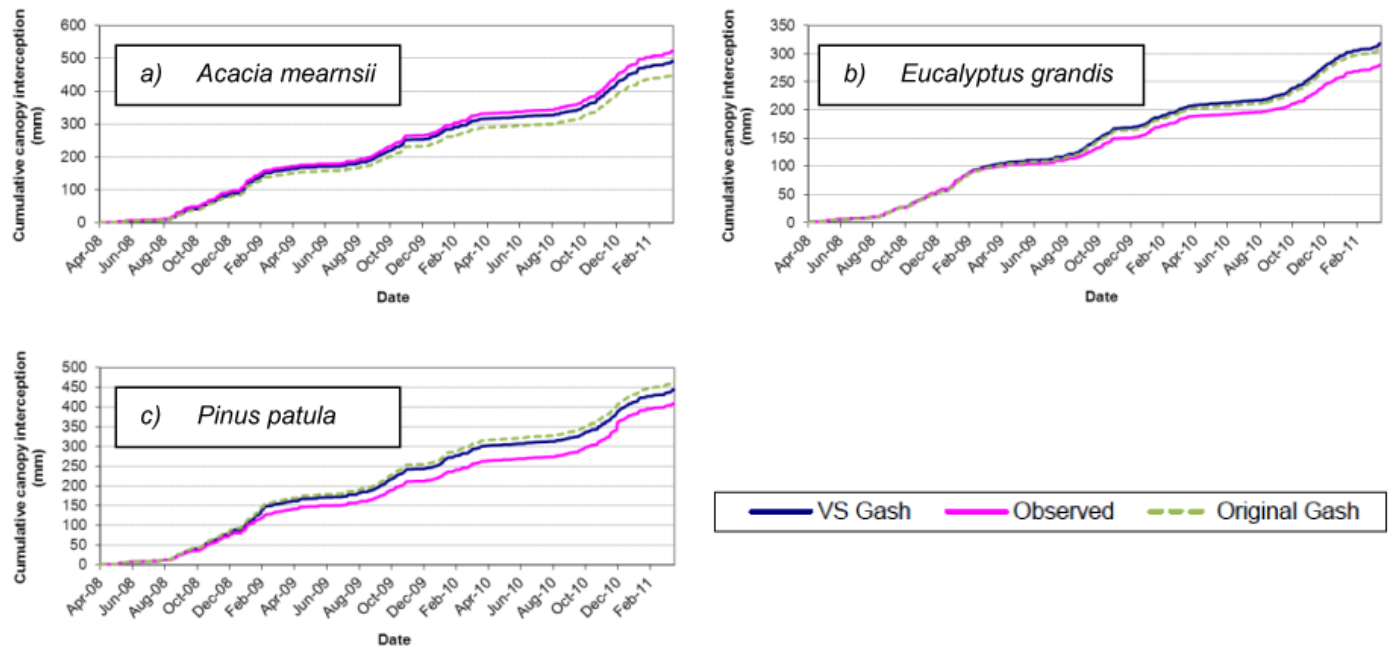

Fig. 2. Cumulative observed and modelled canopy interception simulated with the Variable Storage Gash model and original Gash model from April 2008 to March 2011 at Two Streams.

Table 3. Summary of observed and modelled canopy interception results for April 2008 to March 2011 using the original Gash model and Variable Storage (VS) Gash model.

\begin{tabular}{|c|c|c|c|c|c|c|c|c|c|}
\hline Genus & $\begin{array}{r}\text { Gross } \\
\text { Precip. } \\
(\mathrm{mm})\end{array}$ & $\begin{array}{r}\text { Observed } \\
\text { canopy } \\
\text { interception } \\
(\mathrm{mm})\end{array}$ & $\begin{array}{r}\text { Observed } \\
\text { canopy } \\
\text { interception } \\
(\%)\end{array}$ & $\begin{array}{r}\text { VS Gash } \\
\text { canopy } \\
\text { interception } \\
(\mathrm{mm})\end{array}$ & $\begin{array}{r}\text { VS Gash } \\
\text { canopy } \\
\text { interception } \\
(\%)\end{array}$ & $\begin{array}{r}\text { Original } \\
\text { Gash } \\
\text { canopy } \\
\text { interception } \\
(\mathrm{mm})\end{array}$ & $\begin{array}{r}\text { Original } \\
\text { Gash } \\
\text { canopy } \\
\text { interception } \\
(\%)\end{array}$ & $\begin{array}{r}\text { Original } \\
\text { Gash } \\
\text { Relative } \\
\text { Error } \\
(\%)\end{array}$ & $\begin{array}{r}\text { VSGash } \\
\text { Relative } \\
\text { Error } \\
(\%)\end{array}$ \\
\hline Eucalyptus & 1884.7 & 280.4 & 14.9 & 318.4 & 16.9 & 309.7 & 16.4 & 10.4 & 13.4 \\
\hline Acacia & 1884.7 & 522.4 & 27.7 & 501.4 & 26.6 & 451.4 & 24.0 & 13.6 & 4.0 \\
\hline Pinus & 1909.7 & 408.7 & 21.4 & 444.1 & 23.3 & 464.9 & 24.3 & 13.8 & 8.9 \\
\hline
\end{tabular}

- Eucalyptus grandis $=0.24 \mathrm{~mm}( \pm 0.04 \mathrm{~mm})$

- Acacia mearnsii $=0.63 \mathrm{~mm}( \pm 0.06 \mathrm{~mm})$

- Pinus patula $=0.51 \mathrm{~mm}( \pm 0.03 \mathrm{~mm})$

$S_{\mathrm{e}}^{\max }=q v_{0}\left(\right.$ i.e. $\left.q=\frac{S_{\mathrm{e}}^{\max }}{v_{0}}\right)$

where $q$-drop retention factor $\left(\mathrm{mm}^{-2}\right) ; S_{\mathrm{e}}^{\max }-$ is the maximum storage of water retained by a canopy element $(\mathrm{mm})$, and $v_{0}$ is the mean volume of the raindrop $\left(\mathrm{mm}^{3}\right)$ with almost zero kinetic energy.

The term maximum storage capacity $\left(S_{\mathrm{c}}^{\max }\right)$ which is obtained when the canopy is wetted with drops of almost zero kinetic energy and is defined as

$S_{\mathrm{c}}^{\max }=S_{\mathrm{e}}^{\max } \mathrm{LAI}=q v_{0} \mathrm{LAI}$

The storage capacity $\left(S_{\mathrm{c}}\right)$ for non-zero kinetic energy drops can therefore be defined as:

$S_{\mathrm{c}}=S_{\mathrm{e}} \mathrm{LAI}=q v \mathrm{LAI}$
The drop volume $(v)\left(\mathrm{mm}^{3}\right)$ is estimated using the MarshallPalmer (Marshall and Palmer, 1948) equation:

$v=a R^{\mathrm{b}}$

where $a=0.124, b=0.63$, and are unitless parameters of a power function to scale $\mathrm{mm} \mathrm{h}^{-1}$ to $\mathrm{mm}^{3}$ (Hall, 2003). $R-$ Gross rainfall rate or intensity $\left(\mathrm{mm} \mathrm{h}^{-1}\right)$.

In order to operate the model for a particular vegetation type, two vegetation specific parameters $S_{\mathrm{c}}^{\max }$ and $S_{\mathrm{e}}^{\max }$ are required. A functional relationship between $S_{\mathrm{c}} / S_{\mathrm{c}}^{\max }$ (Eq. 19a and b) and $v$ is also required. Calder (1996) developed the following empirical exponential relationship from rainfall simulator experiments:

$S_{\mathrm{c}} / S_{\mathrm{c}}^{\max }=1$ for $v<0.065$

$S_{\mathrm{c}} / S_{\mathrm{c}}^{\max }=0.5+0.73 . \exp (-5.5 . v)$ for $v>0.065$

Then, rearranging the Marshall-Palmer (Marshall and Palmer, 1948) equation to determine $R$ for $v<0.065$ it can be established that $S_{\mathrm{c}} / S_{\mathrm{c}}^{\max }=1$ for $R<0.36 \mathrm{~mm} \mathrm{~h}^{-1}$. From field measurements of LAI and storage capacity for events with $R<0.36 \mathrm{~mm} \mathrm{~h}^{-1}$, the vegetation/species specific $S_{\mathrm{e}}^{\max }$ 


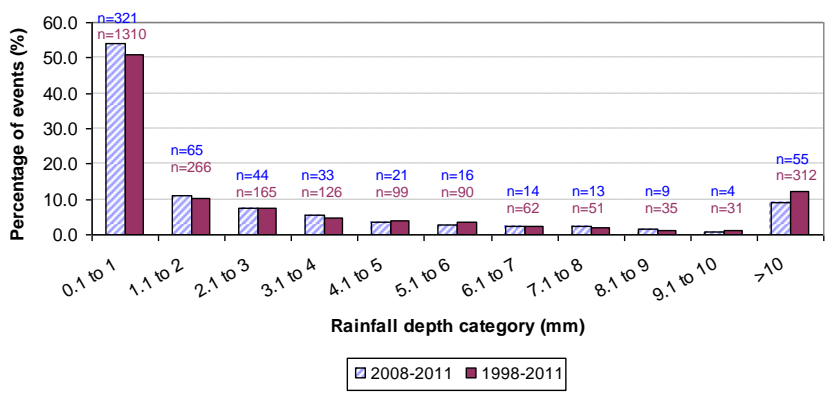

Fig. 3. Percentage of rainfall events per rainfall depth category $(n=$ 595 and $n=2577$ ) for the periods April 2008 to March 2011 and September 1998 to March 2011, respectively.

can be calculated. By knowing the $v$ from the MarshallPalmer (Marshall and Palmer, 1948) equation and $S_{\mathrm{c}}^{\max }$, the variable $S_{\mathrm{c}}$ can be calculated as the product of $S_{\mathrm{c}} / S_{\mathrm{c}}^{\max }$ and $S_{\mathrm{c}}^{\max }$.

The maximum elemental storage $\left(S_{\mathrm{e}}^{\max }\right)$ does not change with the growth of the tree due to the linear relationship between $S_{\mathrm{c}}^{\max }$ and LAI. The linear relationship between storage capacity and LAI for a given vegetation type of constant physiognomy and configuration has been corroborated by the results of Aston (1979), Von-Hoyningen-Huene (1981), Pitman (1989), Liu (1998) and van Dijk and Bruijnzeel (2011b).

\subsection{Climatic variables}

The climatic forcing variables required for the VS Gash model are gross precipitation $\left(P_{\mathrm{g}}\right)$, mean gross rainfall rate $(R)$ and mean evaporation rate $(E)$ per event (Table 1$)$. In this study the Penman-Monteith reference potential evaporation was used with the stomatal resistance term $\left(r_{\mathrm{s}}\right)$ equal to zero for the period that the rainfall event took place.

\subsection{Model validation and verification}

The 'VS Gash model and litter interception model were validated by testing that the individual components of the models were conceptually sound and that the model was programmed correctly and gave consistent and realistic outputs. Using the split-sample method (Klemeš, 1986), the model parameters were calibrated using the data from the first year of study (April 2008-April 2009), which accounted for both summer and winter conditions. The remaining data from May 2009 to March 2011 was used to validate the calibrated parameters. The model was then run for the entire study period and the time series of the model output was used to verify the model output.

\section{Litter interception model}

A smaller, although significant, role is played by litter interception. According to Schaap and Bouten (1997) in their study of a Douglas fir stand, as much as half of the total forest evaporation may originate from the canopy and litter interception processes. The water holding capacity of the surface horizon depends on the surface area of the material, similar to the storage of the canopy. Researchers have shown that litter interception is governed primarily by the moisture holding capacity and initial storage capacity of the litter, but also by the evaporative demand following the rainfall event (Rowe, 1955; Helvey and Patric, 1965). Throughfall that reaches the dry litter gradually increases the litter moisture to field capacity and then saturation. The saturated litter can lose as much as $75 \%$ of its moisture in the first four days of drying (Blow, 1955; Jacobsz, 1987) and reaches an equilibrium after 10 to 12 days (Metz, 1958).

\section{$5 \quad$ Litter model conceptualization}

The litter interception model is based on the drying curves of E. grandis, A. mearnsii and P. patula, developed from samples collected at the Two Streams study site. A drying curve for naturally drying litter samples is determined from calculations of moisture content in the litter in the days following a saturating rainfall event following the approach of Jewitt (1991). A representative sample of the litter was collected for each of the three genera and placed in an aluminium foil tray that had holes punched into it to allow for free drainage of water. The samples were then dried in an oven overnight at $100^{\circ} \mathrm{C}$ for $24 \mathrm{~h}$. Once the samples were dried, they were weighed. They were then saturated and weighed again to obtain the litter storage capacity as shown in Table 2. The samples were then weighed daily for twelve days. This process was repeated twice annually for the three years of the study, to obtain the idealized drying curves illustrated in Fig. 1. The drying curves were derived from a combination of the samples dried in the laboratory and under a shaded outdoor area.

The drying curve equations, litter storage capacity and litter thickness for each of the three genera are summarized in Table 2.

The litter model, which is programmed in a Microsoft Excel spreadsheet, is site specific, as the litter characteristics will vary between species, age, litter thickness and climatic region. The model uses the daily throughfall simulated using the VS Gash model as an input. A "bookkeeping" method is then used to calculate the litter moisture content depending on the preceding dry days following the wetting of the litter from the drying curves in Table 2. Once saturation (storage capacity) is reached, any excess throughfall will infiltrate to the soil. 
Table 4. Summary of Variable Storage Gash model and observed canopy interception statistics for the period April 2008 to March 2011.

\begin{tabular}{|c|c|c|c|c|c|c|}
\hline \multirow[t]{2}{*}{ Statistic } & \multicolumn{2}{|c|}{ Eucalyptus grandis } & \multicolumn{2}{|c|}{ Acacia mearnsii } & \multicolumn{2}{|c|}{ Pinus patula } \\
\hline & Modelled & Observed & Modelled & Observed & Modelled & Observed \\
\hline Sample size & 1066 & 1066 & 1066 & 1066 & 1066 & 1066 \\
\hline Mean $(\mathrm{mm})$ & 0.30 & 0.26 & 0.47 & 0.49 & 0.42 & 0.38 \\
\hline Standard Error $(\mathrm{mm})$ & 0.015 & 0.014 & 0.029 & 0.030 & 0.022 & 0.025 \\
\hline Standard Deviation (mm) & 0.48 & 0.44 & 0.93 & 0.97 & 0.72 & 0.81 \\
\hline Sample Variance $(\mathrm{mm})$ & 0.23 & 0.19 & 0.86 & 0.95 & 0.52 & 0.64 \\
\hline RMSE & \multicolumn{2}{|c|}{0.24} & \multicolumn{2}{|c|}{0.26} & \multicolumn{2}{|c|}{0.54} \\
\hline$R^{2}$ & \multicolumn{2}{|c|}{0.76} & \multicolumn{2}{|c|}{0.83} & \multicolumn{2}{|c|}{0.56} \\
\hline
\end{tabular}
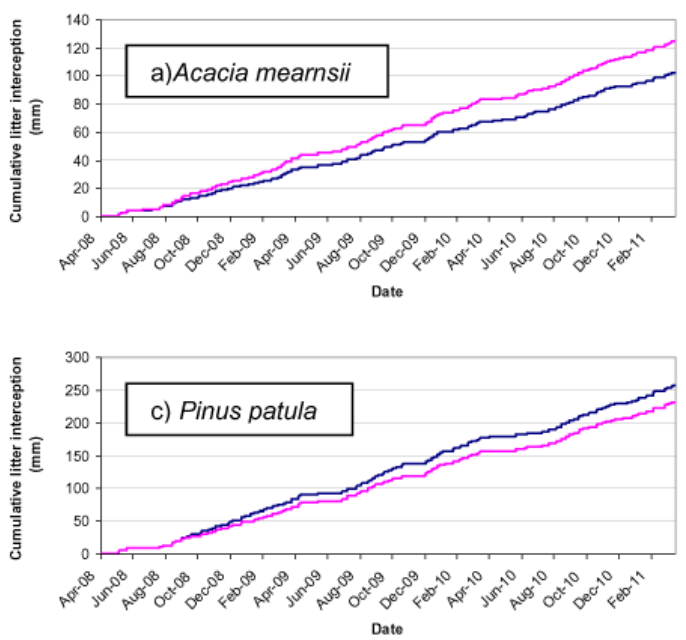
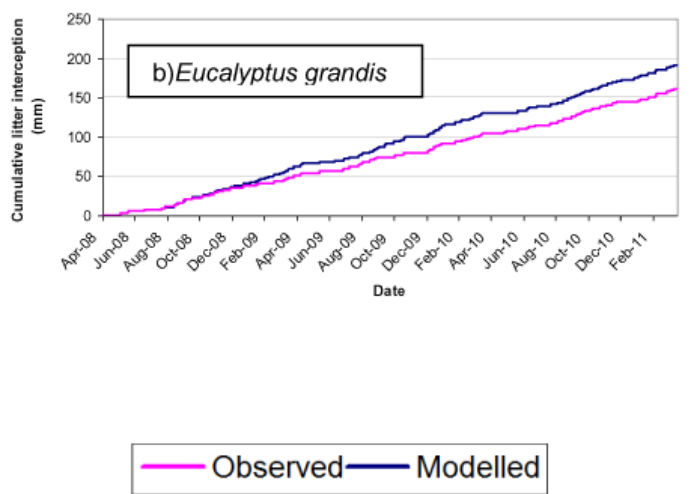

Fig. 4. Cumulative observed and modelled litter interception simulated using idealised drying curves for three commercial forestry species at Two Streams for the period April 2008 to March 2011.

\section{Results and discussion}

\subsection{Canopy interception}

The importance of canopy interception in the water balance of a forested catchment is illustrated in Fig. 2 as well as in Table 3, showing both the observed and modelled results of this study. Once the models described were validated, canopy and litter interception were then simulated using historical rainfall and evaporation data obtained from the CSIR from September 1998 to March 2011. The maximum elemental storage $\left(S_{\mathrm{e}}^{\max }\right)$ parameter was calibrated during the period April 2008 to April 2009 to account for both summer and winter rainfall. The parameters used in validating the models during the study period from April 2009 to March 2011 were kept constant, with only the rainfall and evaporation data changing when modelling from September 1998 to March 2011.

The results of this study show that the simulated canopy interception ranges from $16.9 \%$ to $26.6 \%$ for $E$. grandis and A. mearnsii, respectively, and $23.3 \%$ of gross precipitation is intercepted by P. patula. Figure 2a, b and c illustrate that the simulated E. grandis, A. mearnsii and P. patula canopy interception results, summarized in Table 3 , corresponded well with the observed data, with the difference between the simulated and observed ranging between $1.1 \%$ and $2.0 \%$. This corresponds to a relative error of between $4.0 \%$ and $13.4 \%$ between simulated and observed results.

Rainfall interception from the canopy was responsible for a large amount of the total evaporation from the forested areas, and perhaps more than many may anticipate, as shown in Table 3. A noticeable result is that Eucalyptus grandis has the lowest interception of the three species in this study, even though it has the highest LAI. The small difference between the observed and simulated canopy interception can therefore be attributed to the successful estimation of the canopy storage capacity. While E. grandis has the highest LAI, it also had the smallest elemental storage $\left(S_{\mathrm{e}}\right)$ and canopy retention $(q)$, therefore having the smallest canopy storage capacity. What is also noticeable from Fig. 2 and Table 3 is that for $E$. grandis the original and VS Gash models performed very similarly and had relative errors of 10.4 and $13.4 \%$ respectively. This is because the $S_{\mathrm{c}}$ of $E$. grandis does not 
Table 5. Summary of gross observed and modelled litter interception results from April 2008 to March 2011.

\begin{tabular}{lrrrrrr}
\hline & $\begin{array}{r}\text { Gross } \\
\text { Precipitation } \\
(\mathrm{mm})\end{array}$ & $\begin{array}{r}\text { Observed } \\
\text { litter } \\
\text { interception } \\
(\mathrm{mm})\end{array}$ & $\begin{array}{r}\text { Observed } \\
\text { intter }\end{array}$ & $\begin{array}{r}\text { Modelled } \\
\text { litter }\end{array}$ & $\begin{array}{r}\text { Modelled } \\
\text { litter }\end{array}$ & $\begin{array}{r}\text { Relative } \\
\text { Genus }\end{array}$ \\
\hline Eucalyptus & 1884.7 & 160.4 & 8.5 & 191.1 & 10.1 & 18.8 \\
Acacia & 1884.7 & 124.7 & 6.6 & 102.1 & 5.4 & 18.2 \\
Pinus & 1909.7 & 231.2 & 12.1 & 255.9 & 13.4 & 10.7 \\
\hline
\end{tabular}

Table 6. Summary of the litter interception model and observed litter interception statistics for the period April 2008 to March 2011.

\begin{tabular}{|c|c|c|c|c|c|c|}
\hline \multirow[t]{2}{*}{ Statistic } & \multicolumn{2}{|c|}{ Eucalyptus grandis } & \multicolumn{2}{|c|}{ Acacia mearnsii } & \multicolumn{2}{|c|}{ Pinus patula } \\
\hline & modelled & observed & modelled & observed & modelled & observed \\
\hline Sample size & 1066 & 1066 & 1066 & 1066 & 1066 & 1066 \\
\hline Mean (mm) & 0.18 & 0.15 & 0.10 & 0.12 & 0.24 & 0.21 \\
\hline Standard error $(\mathrm{mm})$ & 0.016 & 0.014 & 0.01 & 0.01 & 0.023 & 0.021 \\
\hline Standard deviation $(\mathrm{mm})$ & 0.51 & 0.46 & 0.28 & 0.33 & 0.74 & 0.68 \\
\hline Sample variance $(\mathrm{mm})$ & 0.26 & 0.21 & 0.08 & 0.11 & 0.54 & 0.46 \\
\hline RMSE & \multicolumn{2}{|c|}{0.24} & \multicolumn{2}{|c|}{0.10} & \multicolumn{2}{|c|}{0.23} \\
\hline$R^{2}$ & \multicolumn{2}{|c|}{0.77} & \multicolumn{2}{|c|}{0.85} & \multicolumn{2}{|c|}{0.83} \\
\hline
\end{tabular}

change greatly with a change in rainfall intensity as shown by Bulcock and Jewitt (2012). Conversely, A. mearnsii has a high storage capacity and is sensitive to changes in rainfall intensity as highlighted by Bulcock and Jewitt (2012). In this case, the VS Gash model performed significantly better than the original Gash model with relative errors of 4.0 and $13.6 \%$, respectively. It is therefore important to consider the retention characteristics of the canopy when modelling canopy interception and not just base the estimation of the canopy storage capacity on LAI. Furthermore, the estimation of canopy storage capacity took the rainfall intensity into account, which was an important consideration in a mistbelt area where there are a large number of low intensity events but the bulk of the rainfall comes from the relatively few large, high intensity storms. From Fig. 3 it can be seen that $50.8 \%$ of the rainfall events during this study period were less than $1 \mathrm{~mm}^{-1}$ day $^{-1}$, with $10.9 \%$ and $7.4 \%$ of the events being between 1 and $2 \mathrm{~mm}$ and 2 and $3 \mathrm{~mm}$, respectively. The gross rainfall record from September 1998 to March 2011 showed a very similar trend in the gross rainfall distribution to that recorded during the study period. This indicates that the gross rainfall during the study period was typical for the catchment. In these small events almost $100 \%$ of the gross rainfall would be intercepted by the canopy and the remainder by the litter (Jacobsz, 1987). It must be noted that the raingauges did not have a mist interceptor, but any mist captured by the canopy would be accounted for by throughfall if there is a rainfall event that occurs after the canopy has been wetted by mist (i.e. that canopy storage capacity has been partially or fully filled by the mist interception), so the interception amount may in fact be slightly underestimated.

The performance of the VS Gash model in comparison with the observed data for the period April 2008 to March 2011 is summarised in Table 4.

From Table 4 it can be seen that the descriptive statistics for observed and modelled canopy interception correspond well. The worst performing being $P$. patula with a $R^{2}$ and root mean square error (RMSE) of 0.56 and 0.54 , respectively. The $R^{2}$ for $E$. grandis and $A$. mearnsii are 0.76 and 0.83 , respectively, as well as low RMSE values of 0.24 and 0.26 , indicating that the model performed at an acceptable level.

\subsection{Litter interception}

The results of the litter interception study are illustrated in Fig. 4 and summarised in Table 5.

This study shows that litter interception has an important role in the forest hydrological cycle, with as much as $13.4 \%$ of gross precipitation being intercepted by the $16 \mathrm{yr}$ old $P$. patula litter. The results of the cumulative modelled and observed litter interception are illustrated in Fig. 4. The model results were good, with the actual difference between modelled and observed for E. grandis, A. mearnsii and P. patula being $1.6 \%, 1.2 \%$ and $1.3 \%$, respectively. This corresponds with a relative error of $18.8 \%, 18.2 \%$ and $10.7 \%$ respectively. From the summarized results in Table 5, it can be seen that $A$. mearnsii has the lowest litter interception with between $5.4 \%$ and $6.6 \%$ of gross precipitation being 

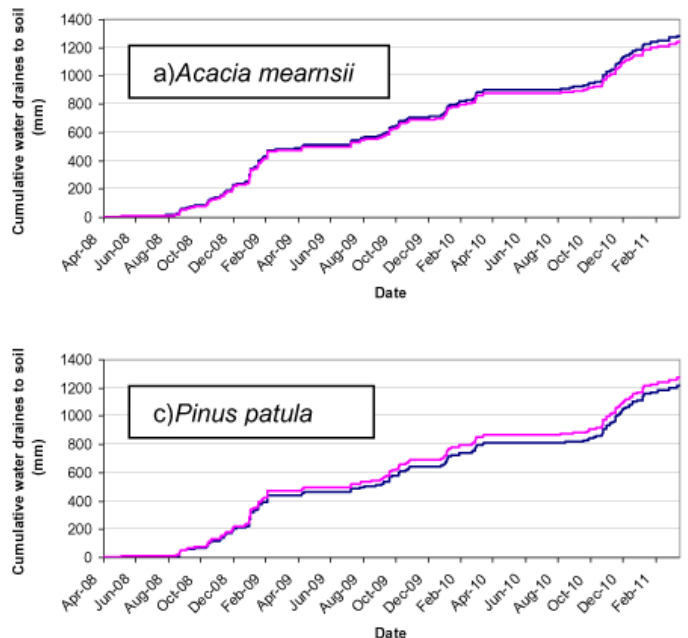
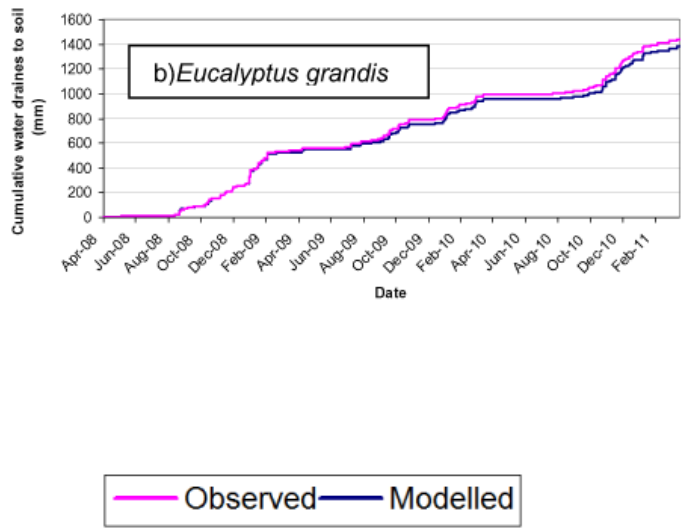

Fig. 5. Cumulative observed and modelled water that drains into soil from April 2008 to March 2011 for three species at Two Streams.

Table 7. Summary of observed and modelled water that drained to soil for April 2008 to March 2011.

\begin{tabular}{lrrrrrr}
\hline & & $\begin{array}{r}\text { Observed } \\
\text { water } \\
\text { Gross } \\
\text { drained } \\
\text { to soil } \\
(\mathrm{mm})\end{array}$ & $\begin{array}{r}\text { Observed } \\
\text { water } \\
\text { drained } \\
\text { to soil } \\
(\%)\end{array}$ & $\begin{array}{r}\text { Modelled } \\
\text { water } \\
\text { drained } \\
\text { to soil } \\
(\mathrm{mm})\end{array}$ & $\begin{array}{r}\text { Modelled } \\
\text { water } \\
\text { drained } \\
\text { to soil } \\
(\%)\end{array}$ & $\begin{array}{r}\text { Relative } \\
\text { Error } \\
(\%)\end{array}$ \\
\hline Eucalyptus & 1884.7 & 1437.0 & 76.2 & 1375.2 & 72.9 & 4.3 \\
Acacia & 1884.7 & 1237.7 & 65.7 & 1281.5 & 64.3 & 2.1 \\
Pinus & 1909.7 & 1269.8 & 66.5 & 1209.7 & 63.3 & 4.8 \\
\hline
\end{tabular}

intercepted. E. grandis and P. patula had the highest modelled and observed litter interception with the modelled results being $10.1 \%$ and $13.4 \%$, respectively.

Relative to the depth of litter (cf. Table 2), E. grandis has a high litter interception value. This may be due to the shape of the leaves that form the litter layer. The broad leaves act as "cups" that catch the throughfall, and provide very little resistance to the evaporative process. The simple litter interception model based on idealised drying curves is dependent upon the accuracy of the canopy interception model as the modelled throughfall is used as the model input. If the throughfall or canopy interception is modelled poorly, then the input into the litter interception model will induce a systematic error from the beginning of the simulation.

The statistics describing the performance of the litter interception model derived from the drying curves in comparison with the observed data measured at Two Streams for the period April 2008 to March 2011 is summarised in Table 6.

From Table 6 it can be seen that mean, standard error, standard deviation and sample variance for the modelled and observed litter interception results are similar, indicating that the model performed well. This is also seen by the RMSE values for E. grandis, A. mearnsii and P. patula being between 0.1 and 0.24 . The $R^{2}$ values are also very good with
A. mearnsii having the highest at 0.85 and $E$. grandis the lowest at 0.77 . To determine how the two models performed together, the cumulative water that drains into the soil was also considered.

\subsection{Water that drains into the soil}

The observed results for the water that drains into the soil, i.e. the "useable water", are a good indicator of how the canopy and litter interception models performed together to represent the entire interception process. This is because the measured water that drains into the soil is measured as a separate entity and is not dependant on measured throughfall to calculate, as is the case with litter interception. Therefore, if the canopy and litter models did not perform well, then the modelled water that drained to the soil would not correspond well to the observed results, as the litter model depends on the modelled throughfall as an input. The comparative results of the cumulative modelled and observed water that drains into the soil is illustrated in Fig. 5.

Figure 5 shows that the modelled and observed results compare well, illustrating that the combination of the relatively complex canopy interception model and simple litter 
Table 8. Summary of modelled and observed water that drains into the soil statistics for the period April 2008 to March 2011.

\begin{tabular}{|c|c|c|c|c|c|c|}
\hline \multirow[t]{2}{*}{ Statistic } & \multicolumn{2}{|c|}{ Eucalyptus grandis } & \multicolumn{2}{|c|}{ Acacia mearnsii } & \multicolumn{2}{|c|}{ Pinus patula } \\
\hline & modelled & observed & modelled & observed & modelled & observed \\
\hline Sample size & 1066 & 1066 & 1066 & 1066 & 1066 & 1066 \\
\hline Mean (mm) & 1.29 & 1.35 & 1.20 & 1.16 & 1.13 & 1.20 \\
\hline Standard error (mm) & 0.134 & 0.141 & 0.131 & 0.123 & 0.128 & 0.132 \\
\hline Standard deviation $(\mathrm{mm})$ & 4.36 & 4.44 & 4.10 & 4.01 & 4.13 & 4.20 \\
\hline Sample variance (mm) & 19.05 & 19.14 & 16.80 & 16.33 & 17.10 & 17.60 \\
\hline RMSE & \multicolumn{2}{|c|}{0.33} & \multicolumn{2}{|c|}{0.27} & \multicolumn{2}{|c|}{0.55} \\
\hline$R^{2}$ & \multicolumn{2}{|c|}{0.83} & \multicolumn{2}{|c|}{0.85} & \multicolumn{2}{|c|}{0.81} \\
\hline
\end{tabular}

Table 9. Summary of all results modelled from September 1998 to March 2011 at the Two Streams research catchment.

\begin{tabular}{|c|c|c|c|c|c|c|c|}
\hline Genus & $\begin{array}{r}\text { Gross } \\
\text { Precipitation } \\
(\mathrm{mm})\end{array}$ & $\begin{array}{r}\text { Modelled } \\
\text { canopy } \\
\text { interception } \\
(\mathrm{mm})\end{array}$ & $\begin{array}{r}\text { Modelled } \\
\text { canopy } \\
\text { interception } \\
(\%)\end{array}$ & $\begin{array}{r}\text { Modelled } \\
\text { litter } \\
\text { interception } \\
(\mathrm{mm})\end{array}$ & $\begin{array}{r}\text { Modelled } \\
\text { litter } \\
\text { interception } \\
(\%)\end{array}$ & $\begin{array}{r}\text { Modelled } \\
\text { water } \\
\text { drained } \\
\text { to soil } \\
(\mathrm{mm})\end{array}$ & $\begin{array}{r}\text { Modelled } \\
\text { water } \\
\text { drained } \\
\text { to soil } \\
(\%)\end{array}$ \\
\hline Eucalyptus & 11145.5 & 1805.6 & 16.2 & 869.3 & 7.8 & 8470.6 & 76.0 \\
\hline Acacia & 11145.5 & 3020.4 & 27.1 & 702.2 & 6.3 & 7422.9 & 66.6 \\
\hline Pinus & 11145.5 & 2708.4 & 24.3 & 1605.0 & 14.4 & 6832.2 & 61.3 \\
\hline
\end{tabular}

interception model work well together. The results are summarized in Table 7.

From Table 7, it can be seen that the modelled water that drains into the soil is $3.3 \%, 1.4 \%$ and $3.2 \%$ higher than the observed results for E. grandis, A. mearnsii and P. patula, respectively, with between $63.3 \%$ and $72.9 \%$ of gross precipitation reaching the soil. This corresponds to a relative error of $4.3 \%, 2.1 \%$ and $4.8 \%$ for E. grandis, A. mearnsii and $P$. patula, respectively, as shown in Table 7 .

The statistics of the performance of the model derived from the drying curves to estimate the water that drains into the soil in comparison with the observed data measured at Two Streams for the period April 2008 to March 2011 are summarised in Table 8 .

From Table 8 it can be seen that the combination of the VS Gash model and the litter interception model derived from drying curves worked well, as the descriptive statistics for the modelled and observed water that drains into the soil are very similar. This is also seen by the high $R^{2}$ values for $E$. grandis, A. mearnsii, and P. patula of $0.83,0.85$ and 0.81 , respectively.

\subsection{Interception for the period 1998-2011}

Based on the results obtained, it is accepted that the model is representative of the processes and on this basis the modelling study was extended to a longer period. The same model variables used to model for the study period between April 2008 to March 2011 was assumed for the extended pe- riod from September 1998 to March 2011. The results of the data simulated for the period from September 1998 to March 2011 are summarized in Table 9.

The simulated results for the study period between April 2008 and March 2011 are similar to those obtained from simulating between September 1998 and March 2011. The difference in the results of the modelled water that drains into the soil for the two periods are $3.1 \%, 2.3 \%$ and $2.0 \%$ for E. grandis, A. mearnsii and P. patula, respectively. This once again highlights that the climatic conditions during the study period are typical of the catchment as the difference in canopy and litter interception as well as water that drains into soil are very similar.

\section{Conclusions}

This study confirms that interception plays a very important role in the forest hydrological cycle, with between $63.3 \%$ and $72.9 \%$ of gross precipitation being available water that drains into the soil, after the losses due to canopy and litter interception for the three year period April 2008 to March 2011. This also highlights the importance of including and accurately representing canopy and litter interception in water resources planning models. Both the Variable Storage Gash model and litter interception models performed well. The VS Gash model is conceptually complex, but can be applied with readily available data. Although the input data requirements are greater than the original Gash model (Gash, 1979), an added consideration of the change in 
canopy storage capacity depending on the rainfall intensity has been added and is considered an important conceptual advance. This improvement is particularly noticeable in forest stands that have a high storage capacity relative to their LAI and which are sensitive to changes in rainfall intensity. This addition along with the consideration for the canopy water retention characteristics have resulted in the canopy interception simulations being very good. This point was highlighted by considering that $E$. grandis had the highest LAI, but had the lowest canopy interception due to its low water retention because of the angle at which the large leaves hang, as well as their smooth, waxy surface. Conversely, the A. mearnsii had the second largest LAI, but the largest canopy interception, due to the high water retention characteristics of its small pinnately compound leaves. While the VS Gash model may be considered complex, the litter interception model, which is based on idealised drying curves, is very simple. However, although the model may be simple, it performs well. This can be explained by the fact that unlike canopy interception - which is strongly influenced by many factors such as storage capacity, potential evaporation, rainfall intensity, rainfall duration amongst others - litter interception is mostly dependant on storage capacity and modelling it is dependent on the accurate estimation thereof. This is because the evaporative drivers under the canopy such as wind, temperature and radiation are moderated relative to those above canopy. Therefore, as long as the inputs of simulated throughfall from the VS Gash model are adequate and the litter storage capacity is estimated accurately, the model should perform well. It could in fact be argued that the Variable Storage Gash model and litter interception models should not be considered as separated models, but as one model that simulates total interception (i.e. canopy + litter interception). Therefore, despite the introduction of new parameters to the model, it is argued that the approach adopted is aligned with the suggestion that any model should attain a "requisite simplicity" by discarding some detail but still maintain conceptual clarity and scientific rigour (Stirzaker et al., 2010). Extending the study to other sites in different climate regions will show whether this is indeed the case.

Acknowledgements. The authors wish to thank Miriam CoendersGerrits, Tanya Euser and the anonymous reviewer for their valuable and constructive comments.

Edited by: F. Fenicia

\section{References}

Aston, A. R.: Rainfall interception by eight small trees, J. Hydrol., 42, 383-396, 1979.

Battaglia, M., Sands, P., White, D., and Mummery, D.: CABALA: a linked carbon, water and nitrogen model of forest growth for silvicultural decision support, Forest Ecol. Manag., 193, 251-282, 2004.
Blow, F. E.: Quantity and hydrologic characteristics of litter and upland oak forests in eastern Tennessee, J. Forest, 53, 190-195. 1955.

Bulcock, H. H. and Jewitt, G. P. W.: Field data collection and analysis of canopy and litter interception in commercial forest plantations in the KwaZulu-Natal Midlands, South Africa, Hydrol. Earth Syst. Sci., 16, 3717-3728, doi:10.5194/hess-16-37172012, 2012.

Calder, I. R.: A stochastic model of rainfall interception, J. Hydrol., 89, 65-71, 1986.

Calder, I. R.: Dependence of rainfall interception on drop size: 1. Development of the two layer stochastic model, J. Hydrol., 170, 79-86, 1996.

Cuartus, L. A., Tomasella, J., Nobre, A. D., Hodnett, M. G., Waterloo, M. J., and Múnera, J. C.: Interception water-partitioning dynamics for a pristine rainforest in Central Amazonia: Marked differences between normal and dry years, Agr. Forest Meteorol., 145, 69-83, 2007.

Everson, C., Moodley, M., Gush, M., Jarmain, C., Govender, M., and Dye, P.: Can effective management of riparian zone vegetation significantly reduce the cost of catchment management and enable greater productivity of land resources, Water Research Commission, Pretoria, Report K5/1284, 2006.

Gash, J. H. C.: An analytical model of rainfall interception by forests, Q. J. Roy. Meteorol. Soc., 105, 43-55, 1979.

Gash, J. H. C., Lloyd, C. R., and Lachaud, G.: Estimating sparse forest rainfall interception with an analytical model, J. Hydrol., 170, 79-86, 1995.

Gash, J. H. C., Wright, I. R., and Lloyd, C. R.: Comparative estimates of interception loss from three coniferous forests in Great Britain, J. Hydrol., 48, 89-105, 1980.

Gazarini, L. C., Araujo, M. C. C., Borralho, N., and Pereira, J. S.: Plant area index in Eucalyptus globulus plantations determined indirectly by a light interception method, Tree Physiol., 7, 107113, 1990.

Gerrits, A. M. J., Savenije, H. H. G., Hoffmann, L., and Pfister, L.: New technique to measure forest floor interception - an application in a beech forest in Luxembourg, Hydrol. Earth Syst. Sci., 11, 695-701, doi:10.5194/hess-11-695-2007, 2007.

Gerrits, A. M. J., Pfsiter, L., and Savenije, H. H. G.: Spatial and temporal variability of canopy and forest floor interception in a beech forest, Hydrol. Process., 24, 3011-3025. 2010.

Hall, R. L.: Interception loss as a function of rainfall and forest types: stochastic modelling for tropical canopies revisited, J. Hydrol., 280, 1-12, 2003.

Helvey, J. D. and Patric, J. H.: Canopy and litter interception of rainfall by hardwoods of the eastern United States, Water Resour. Res., 1, 193-206, 1986.

Jacobsz, M. G.: Rainfall interception by forest litter. Unpublished BSc thesis, Department of Agricultural Engineering, University of Natal, Pietermaritzburg, South Africa, 1987.

Jewitt, G. P. W.: Process studies for the simulation modelling of forest hydrological processes, Unpublished MSc dissertation, Department of Agricultural Engineering, University of Natal, Pietermaritzburg, RSA, 1991.

Klaasens, W., Bosveld, F., and de Water, E.: Water storage and evaporation constituents of rainfall interception, J. Hydrol., 212-213, 36-50, 1998. 
Klemeš, V.: Operational testing of hydrological simulation models, Hydrolog. Sci. J., 31, 13-24, 1986.

Landsberg, J. J. and Waring, R. H.: A generalised model of forest productivity using simplified concepts of radiation use efficiency, carbon balance and partitioning, Forest Ecol. Manag., 95, 209228, 1997.

Liu, S.: Estimation of rainfall storage capacity in canopies of cypress wetlands and slash pine uplands in North-Central Florida, J. Hydrol., 207, 32-41, 1998.

Marshall, J. S. and Palmer, W. M.: The distribution of raindrops with size, J. Meteorol., 5, 165-166, 1948.

McNaughton, K. G. and Jarvis, P. G.: Predicting effects of vegetation changes on transpiration and evaporation, in: Water Deficits and Plant Growth, edited by: Kozlowski, T.T., Vol VII, Academic Press, New York, 1-47, 1983.

Metz, L. J.: Moisture held in pine litter, J. Forest., 56, 36-37, 1958.

Moradkhani, H., Sorooshian, S., Gupta, H., and Houser, P. R.: Dual state-parameter estimation of hydrological models using ensemble Kalman filter, Adv. Water Resour., 28, 135-147, 2005.

Muzylo, A., Llorens, P., Valente, F., Keizer, J. J., Domingo, F., and Gash, J. H. C.: A review of rainfall interception modelling, J. Hydrol, 370, 191-206, 2009.

Pierce, L. L. and Running, S. W.: Rapid estimation of coniferous forest leaf area index using a portable integrating radiometer, Ecology, 69, 1762-1767, 1988.

Pitman, J. L.: Rainfall interception by bracken in open habitats relations between leaf area, canopy storage and drainage rate, J. Hydrol., 105, 317-334, 1989.

Roberts, J. M., Gash, J. H. C., Tani, M., and Bruijnzeel, L. A.: Controls of evaporation in lowland tropical rainforest, in: ForestWater-People in the Humid Tropics, edited by: Bonell, M., Bruijnzeel, L. A., and Kirby, C., Cambridge University Press, Cambridge, 287-313, 2004.
Rowe, P. B.: Effects of the forest floor on disposition of rainfall in pine stands, J. Forest., 53, 342-348, 1955.

Rutter, A. J., Morton, A. J., and Robins, P. C.: A predictive model of rainfall interception in forests II. Generalisation of the model and comparison with observations in some coniferous and hardwood stands, J. Appl. Ecol., 12, 367-384, 1975.

Sampson, D. A. and Lee Allen, H.: Light attenuation in a fourteen year old loblolly pine stand as influenced by fertilization and irrigation, Trees, 13, 80-87, 1998.

Savenije, H. H. G.: The importance of interception and why we should delete the term evapotranspiration from our vocabulary, Hydrol. Process., 18, 1507-1511, 2004.

Schaap, M. G. and Bouten, W.: Forest floor evaporation in a dense Douglas fir stand, J. Hydrol., 193, 97-113, 1997.

Stirzaker, R., Biggs, H., Roux, D., and Cilliers, P.: Requisite simplicities to help negotiate complex problems, AMBIO, 39, 600607, 2010.

Teklehaimanot, Z., Jarvis, P. G., and Ledger, D. C.: Rainfall interception and boundary layer conductance in relation to tree spacing, J. Hydrol., 123, 261-278, 1991.

Van Dijk, A. I. J. M. and Bruijnzeel, L. A.: Modelling rainfall interception by vegetation of variable density using an updated analytical model. Part 1. Model description, J. Hydrol., 247, 230238, 2001a.

Van Dijk, A. I. J. M. and Bruijnzeel, L. A.: Modelling rainfall interception by vegetation of variable density using an updated analytical model. Part 2. Model validation for a tropical upland mixed cropping system, J. Hydrol., 247, 239-262, 2001 b.

Von Hoyningen-Huene, J.: Die interzeption des Niederschlages in landwirtschaftlichen Pflanzenbeständen, Arbeitsbericht Deutscher verband fur Wasserwirtschaft und Kulturbau, DVWK, Braunschwig, Germany, 1981. 